Journal of Southeast Asian

\title{
On the Struggles and Experiences of Southeast Asian American Academics
}

Long T. Bui

University of California, Irvine, longb@uci.edu

Follow this and additional works at: https://docs.lib.purdue.edu/jsaaea

Part of the Asian American Studies Commons, Bilingual, Multilingual, and Multicultural Education Commons, Ethnic Studies Commons, Other Feminist, Gender, and Sexuality Studies Commons, and the Other International and Area Studies Commons

\section{Recommended Citation}

Bui, Long T. (2021) "On the Struggles and Experiences of Southeast Asian American Academics," Journal of Southeast Asian American Education and Advancement. Vol. 16 : Iss. 1, Article 16.

DOI: $10.7771 / 2153-8999.1218$

Available at: https://docs.lib.purdue.edu/jsaaea/vol16/iss1/16

This document has been made available through Purdue e-Pubs, a service of the Purdue University Libraries. Please contact epubs@purdue.edu for additional information.

This is an Open Access journal. This means that it uses a funding model that does not charge readers or their institutions for access. Readers may freely read, download, copy, distribute, print, search, or link to the full texts of articles. This journal is covered under the CC BY-NC-ND license. 


\title{
JSAAEA Journal of Southeast Asian American Education and Advancement
}

Vol. 16 Iss. 1 (2021)

WWW.JSAAEA.org

\section{On the Experiences and Struggles of Southeast Asian American Academics}

\author{
Long T. Bui \\ University of California, Irvine
}

\begin{abstract}
This article examines Southeast Asian American (SEAA) academics in the U.S. academy, relating their complex positionalities within higher education to their communities and societies. While many educational studies have been done on SEAA students, almost none focus on professional scholars and college teachers. Combining cultural-structural critique with close analysis of public writings and personal interviews, the article finds that that SEAA are ignored, marginalized, and/or tokenized in the Ivory Tower due to systemic as well as epistemological issues. It indicates that the public discourse and policies about Southeast Asian faculty not only neglect racial and class hierarchies, but obscure issues of gender equity, professional mentoring, job discrimination, hiring, tenure, and retention. To explain how and why Southeast Asian professors are "missing," this article seeks to: a) build a more critical framework and interdisciplinary methodology for studying SEAA in academia in ways that are intersectional, anti-racist, and comparative, b) challenge dominant narratives of Asians and Asian Americans as they pertain to SEAAs and, c) reveal participants' own stories of agency and belonging in their respective institutions.
\end{abstract}

Keywords: Southeast Asian American, Professor, Faculty, Academia, Ivory Tower

\section{Introduction}

This article concentrates on the struggles of Southeast Asian American (SEAA) professors in the United States. Extensive research has already been done on Southeast Asian heritage students, concentrating primarily on the ways these "at-risk" youth are the "deviant minority" (Museus, 2013). Scholars find their educational hardships and economic experiences swept under the rug, even as this population comes with unique characteristics and challenges (Chhuon \& Hudley, 2008; Wright \& Boun, 2011). Despite individually published candid stories by faculty or studies on specific ethnic groups, little work has been done on the academic of Southeast Asian descent in the aggregate (Quinajon, 2019; Mouavangsou, 2018; Maramba \& Nadal, 2013; Lac, 2020a,

\footnotetext{
(c)

SDRERISHISRESERNEDReaders are free to copy, display, and distribute this article, as long as the work is attributed to the author(s) and the Journal of Southeast Asian American Education \& Advancement, it is distributed for non-commercial purposes only, and no alteration or transformation is made in the work. More details of this Creative Commons license are available at http://creativecommons.org/licenses/by-nc-nd/3.0/. All other uses must be approved by the author(s) or JSAAEA. Journal of Southeast Asian American Education \& Advancement, Vol. 16. Iss. 1. (2021) ISSN: 2153-8999
} 
2020b). Therefore, my article analyzes this heterogenous population collectively as a window into the perplexing power plays in tertiary education and beyond.

Educational research shows that students of color need teachers that share similar backgrounds to teach, guide, and support them even as teachers of color struggle in that capacity (Johnson-Thornton, 2014; Neighbors, 2016; Williams Brown, 2017). Yet, students that claim Southeast Asian ancestry rarely encounter faculty members of the same background who might serve as models of success, encouraging them towards graduate school and eventually an academic career (Uy, 2018; K. Vang, 2016). In usual terms, Southeast Asian American means a regional identity that includes Cambodia, East Timor, West Papua, Vietnam, Brunei, Burma, Malaysia, Laos, Indonesia, Vietnam, Thailand, and the Philippines. In the United States, Southeast Asian has become a convenient marker and racial signifier for Asians from lower income countries, a fact complicated by the community's elites or ethnic Chinese from the region.

While advocating for more Southeast Asian American representation in the professor ranks, I recognize that SEAA is a contested term. Through interviews and a variety of texts, I consider the term's fluidity, countering limited definitions in favor of broader, open definitions. ${ }^{1}$ Thus, I mark the "Southeast Asian American academic" as a distinct group, even as I acknowledge the sociohistorical forces that make that category unstable. Scholars that work on SEAA and my interviewees do not share a singular point of reference. But despite the community's complexity, the "racial lumping" of all Asians obfuscates their perspectives or needs. To assess fully the barriers they face in the professoriate, I contend that education practitioners must decipher the Southeast Asian American issue as an institutional and social problem, but also as a conceptual and discursive one. Insofar as discussions of SEAA as numerically small (invisibility thesis) or not making it (poverty thesis) has barely moved the needle in terms of public opinion or policies about them, there needs to be a reframing of "Asian overrepresentation" in academia. The moment is ripe, given a critical mass of SEAA academics for the first time in the U.S. body academic.

Here, I suggest a closer examination of Southeast Asian American lives in and out of the Ivory Tower. Existing literature on Southeast Asians in higher education documents their resilience, self-efficacy, empowerment, well-being, and coping mechanisms (Kwan, 2015). Given the shortage of disaggregated data on Asians, I provide my own vantage point alongside personal anecdotes from SEAA professors in a variety of ranks, regions, and institutions. Pairing these stories with available sources written by or about SEAA scholars (news interviews, tweets, blogs, essays), I conducted my interviews with a dozen academics across ranks, regions, and backgrounds. I concentrated on scholar-teachers working in the humanities, social sciences, and education - areas where Asian faculty are underrepresented, but where much work on Asian Americans in education has been done. Public writings were selected based on how well they captured a particular point often ignored (e.g., tenure denial repeals) and illuminated issues germane to critical education studies. Personal interviews came through contacts that I gathered from my years as a scholar of Asian American studies. I used a snowball method for locating interviewees, tapping into national networks and meetings like the Southeast Asian American Studies Conference. Almost all my interviews gave permission to use their real names to give a personal aspect to the struggle, but some on the job market chose to remain anonymous due to fear of retaliation. Conjoining others' stories with my own perspective throughout, I delve more deeply into my own positionality in the conclusion.

All the data collected add depth to public knowledge and patterns of research in SEAA education studies. But what distinguishes the personal anecdotes which are self-authored from my semi-structured interviews with key informants is the sense that those who write about their own 
lives tell a different story than those who are directly interviewed. Through one-on-one conversations with informants, I asked difficult probing questions that dug deep into micro-stories that complement published narratives. This combination builds a stronger methodological foundation (textual and intersubjective). My broad outline of what or who the SEAA academic is sharpens understanding of the contexts that they must navigate while in the professoriate. In the process, I utilize anti-racist, comparative, and intersectional frameworks.

To reframe the lifepath of the SEAA college professor as both a micro- and macro-level process, I focus on workplace issues but also discuss graduate school and the academic job market (Le-Huynh, 2008). Therefore, I ask these research questions: How are SEAA academics seen and how are they not recognized in the discourse about Asians in higher education? How does their treatment within academia reflect socio-historical realities and cultural biases? How do SEAA fit within Asian American identity formation and studies? How do individuals fight for their right to work in academia, even if they are pushed out? As this article is firmly anchored in studies of educational diversity, this article contains three foci to: a) inform a more complex framework for studying the experiences of SEAA in academia in ways that are intersectional, anti-racist, and comparative; b) challenge mainstream narratives about SEAAs, by pulling from research on Asian Americans; and c) represent participants' own stories of struggle/victory.

\section{Methodology: Interviews and Stories}

This section introduces key themes about the racialization of higher education, situating my methodology within frameworks and research on Asian/Americans. It addresses the methodological issues that emerge from studying SEAA academics, such as mixing interviews with public writings. I engaged in researcher reflexivity by sharing my own background with informants during the interviews to create genuine dialogue with others who might be going through tribulations that I endured or faced along my own career path.

As the Covid-19 pandemic began in 2020, I received tenure after arduous years of struggle and looking for stability in academia. After obtaining this privilege of permanent security of employment, I was motivated to conduct this study after contemplating my and others' place in the academy while working remotely at home. Social isolation and a global push for more racial justice inspired me to publicize voices in the SEAA academic community. I began reaching out to selected participants to interview who I knew and those I did not know. Through a snowball method, I built a small network of colleagues with whom I trusted for their expertise and diversity of perspectives. What distinguishes my hour-long semi-structured interviews (conducted as an oral history) is the personal nature of facets I can delve into, which self-published authors might neglect or forget.

Public writings were selected based on what personal anecdotes revealed about authors' experiences through academia, and I chose to interview those faculty without published commentaries. These forms of data work together to add to depth of knowledge and patterns of research. They track what can be said as an outcome of private conversation, and what emerges as public self-reflection. Whereas reflexivity brings up biographic details not covered in a clinical setting, a mixture of personal writings/interviews begs the question of how researchers trust sources of knowledge and whether individuals construct their own biases. Such qualitative data may be perceived as lacking intellectual "rigor," but given how minoritized academics are scrutinized, we might ask how freely one can speak about their job in today's politicized current climate and academic "culture wars." 
As the main "instrument" for this study, I end this article by interweaving my positionality in this study's conclusions. As a community-oriented scholar, I hope to ensure rigor and trust in my argument, analysis, and conclusions by couching my selected case studies within other contexts. My "moral authority" as a community scholar is claimed through an affinity with my subjects, despite my difference/privilege as a now tenured cis-male working at a R1 research university (Cousin, 2010). My problematized positionality is necessary to approach qualitative methodology and meet high-standard obligations of critical inquiry (Jones et al., 2013). There will always be thorny issues that come with studying one's own profession and peers.

While most academics who I interviewed gave their formal consent to be named, I did note possible repercussions. At the same time, these scholars are often un/der-recognized for all the invisible labor that they do for the university. There is a catch-22 when studying SEAA scholars: There are so few that they can be identified even with the smallest of demographic information. Yet, by not naming them, those mentors and teachers dwell in the shadows. The ethics of spotlighting individual SEAA scholars remains as challenging as delimiting the general problem of SEAA in the hidden corridors of higher education.

My disciplinary anchoring in critical education/university studies, gender/sexuality studies, global/international studies, ethnic/Asian American studies, and critical refugee studies, informs the kinds of participants and perspectives selected for this study. My analytic combines the bigpicture view with the community-based perspectives and the "nonlinear framework" of Critical Race Theory (CRT) with its interrelated qualities of researching the self, studying the self in relation to others, engaged self-reflection with others, and shifting to systems analysis (Milner, 2007). I employ a robust mode of inquiry based on ontology (who we are in relation to others) and epistemology (how we know what we know). My critique builds on interviews and textual analysis, a methodology following no singular framework, as I draw on various frames which bring valuable insights into my study's population.

With a shortage of data on the SEAA academic population, my focus on storytelling heeds the call by ethnic studies scholar Yen Le Espiritu (2014) to bear witness to stories that change the official narratives about "us." As the evidence of things not seen, these stories are the "open secret" hiding in plain sight. Espiritu says it is not that we are invisible but that we are non-visible and blotted out from the picture. Hence, I outline the problem inherent to thinking (or unthinking) of SEAA in the university, focalizing this institutional problem as something obfuscated within public and academic discourse. While I do not specifically employ her method, I am influenced by the phenomenological approach used by educational scholar Varaxi Yi Borromeo (2008) to evaluate "essence" and uncover what is hidden behind the veil.

Next, I unveil professors' academic pathways to push for better SEAA representation in the academic profession and to urge more robust studies. I discuss an anti-racist approach, then move into an intersectional and comparative frame.

\section{Anti-Racism: Identity and Oppression}

This section deconstructs the category of Southeast Asian/American, drawing inspiration from ethnic studies and education studies that employ Critical Race Theory (CRT), grounded in struggles of race and class. While this section is trained on identity and oppression, later sections build on the previous one on methodology by considering how existing flawed data on SEAA requires storytelling as alternatives. Later sections on comparative and intersectional approaches 
add to the race/class dialectic by considering inter/intra group dynamics and issues of gender/sexuality.

SEAA are rendered (and racialized) as an anomaly with Asian America. Posited as an abject subgroup, their symbolic framing as such circumvents more discussions about migration patterns, human valuing, social class, cultural othering, and labor sorting. These facets are discussed by critical organization studies scholar Rashne Limki (2015) as a differential "mattering" of bodies within the education-as-business model. When they do matter, some of the claims made about SEAA as an anti-model minority or "new model minority" remain wholly uninterrogated (Borromeo, 2018).

Conflicts between white-majority institutions and communities of color are, according to Latinx Studies scholar Stevie Ruiz (2019), derived from a colonial model of education that sorts people according to skin color, gender, race, nationality, and class. For Asians, these conflicts can be traced to Orientalist frameworks that normalize Northeast Asia as the civilizational counterpart to West Europe (Holcombe, 2017). Southeast Asia and their darker populations appear as an afterthought compared to their lighter-skinned northern counterparts.

The Southeast Asian American academic is part and parcel of U.S. racial formation and projects (Omi \& Winant, 2014). Through a tripartite scheme of Black/white/nonwhite, critical legal studies scholar Eduardo Bonilla-Silva (2002) conceptualizes the racial stratification of the new century within a tripartite schema, suggesting that Vietnamese, Hmong, Filipinx, and Laotian Americans compose a "collective Black" category that includes dark-skinned Latinx due to their socioeconomic level. Meanwhile, Koreans, Chinese, and Japanese qualify as "honorary white."

Though Koreans and Filipinx are likely to obtain undergraduate degrees in equal numbers, Filipinx are less likely to go on and earn a higher degree than Koreans (Yamane, 2011). ${ }^{2}$ All told, the number of Filipinx faculty is sorely lacking, despite the flourishing number of undergraduates. This disparity involves community dynamics, but also external factors. Education scholar Edward Joaquin (2014) looked at working Filipinx American professors, finding hostility to their presence in the U.S. academy. This antipathy can be traced back to the Philippine-American War and the early construction of the "Filipino primitive" (See, 2017). Without a critical eye towards the academic-military-industrial complex, what we receive is a neoliberal racial project of producing the generic "Asian scientist" (Chen \& Buell, 2018). Under academic racial capitalism, there is little room for Southeast Asian minds and bodies at universities, merely with an eye on the human capital and economic resources of "Crazy Rich Asians." 3

Representation matters, but the study of SEAA representation remains convoluted. Despite the voluminous studies done, the issue of SEAA in education has resulted in only $2.6 \%$ of all educational publications addressing SEAA in part or wholly (Keo, 2020). An incredible amount of material and reports are published on the plight and "underachievement" of Southeast Asian American students with topics ranging from dropout rates to low graduation numbers. Professional scholars and college teachers, I maintain, are key to unlocking why SEAA are "missing" in higher education (need for more mentors and role models) and why they are misplaced within Asian American critiques. ${ }^{4}$ Too often, it will be glibly mentioned by commentators how SEAA do poorly in school, leaning on a "deficit model" as a convenient foil to say Asians are not all doing well. This debunking of the model minority myth in one fell swoop lacks a more probing analysis. If Asian Americans are the "misrepresented minority," then Southeast Asians are even more misrepresented (Museus et al., 2013). ${ }^{5}$ How then does one study a misrepresented group?

There is always a need for disaggregation on racial data that parallels the push for more demographic data. According to the National Center for Educational Statistics (2018), 76\% of 
faculty in the United States were white, even though only $55 \%$ of students were. ${ }^{6}$ In 2017 , only $5 \%$ of faculty members were "Hispanic" in comparison to $20 \%$ of all undergraduates. Black faculty were severely underrepresented, less than half of the overall proportion for Black undergraduates (6\% vs. 14\%). In contrast, Asian faculty made up a higher portion (11\%) of faculty bodies compared with Asian college students at the national level (7\%). Despite sensationalized reports that Asian applicants are flooding elite schools, the number of full-time Asian undergrads mirror almost the national population that are Asian American (6.5\%). However, the almost doubling of the number of Asians at the graduate level can be attributed to international students and scientists.

Numbers can deceive when used as a blunt measuring tool and instrument of knowledgeproduction, but they can reveal certain truths as well (see Table 1).

\section{Table 1}

Educational Attainment of Population in the United States, 2019, Pew Research Center

\begin{tabular}{lc}
\hline \multicolumn{1}{c}{ Group } & $\begin{array}{c}\text { Percent with Graduate or professional } \\
\text { degree (JD, Masters, PhD, MD etc.) }\end{array}$ \\
\hline All Asians in United States & $\mathbf{2 4 \%}$ \\
Indian & $43 \%$ \\
Bangladeshi & $23 \%$ \\
Chinese & $28 \%$ \\
Korean & $22 \%$ \\
Japanese & $18 \%$ \\
Whites & $14 \%$ \\
All Americans & $\mathbf{1 3 \%}$ \\
Vietnamese & $10 \%$ \\
Filipinx & $10 \%$ \\
Hmong & $6 \%$ \\
Laotian & $3 \%$ \\
Cambodian & $5 \%$ \\
\hline
\end{tabular}

Postgraduate attainment of Black Americans (9\%) and Latinx/Hispanics (5\%) bears closer relationship to SEAA groups, even if those groups' experiences in academia are not necessarily the same. Insofar as "white" category can be broken down, researchers found that working-class East European immigrant scientists receive better treatment overall than Asian faculty due to a Eurocentric bias in academia (Sabharwal, 2011). Chinese, Japanese, Koreans, and especially Indians surpass whites, due to high numbers of educated elites from South and Northeast Asia. ${ }^{7}$

My conceptualization of "Northeast Asians" emerged from my own understanding as a global studies scholar interested in uneven global North and South distinctions, even though other scholars commonly use "East Asian." The Southeast Asian marks one instance of a growth in Global South studies. To introduce this term more forcefully into literature, as a problematic of colonial military originations, we must continually ask why there is an "East Asia" and a "Southeast Asia" (Noor, 2016)? ${ }^{8}$ Due to the Cold War, the circle of "Asia" is narrowly drawn around a small cluster of major ethnoraces and transnational classes. To "give voice" to Southeast Asians in academic spaces means more than adding previously left-out identities and groups. In the context of academic studies, it demands grappling with old racial tropes of that trade in stereotypes of civilized Asian states versus "pre-civilized" barbarous southern societies 
(Hoogervorst, 2012). Countries under U.S. colonial occupation like the Philippines developed a gendered pipeline of pink-collared workers like nurses but not doctor training (Choy, 2003; Clutario, 2013). South Vietnam's economic development differed from U.S. Cold War allies like Taiwan and South Korea, due to differences in colonial policy and foreign aid (Gray, 2013). The status of migrants from those areas reflects those southern histories.

This perceived divergence between north and south grew due to the 1965 Immigration Act, which prioritized the highly skilled migrant (Finkelstein, 2010). Educated elites arrived in large numbers from select countries at the same time as streams of refugees arrived from Southeast Asia, thus driving confusion between being a numerical "minority" racially in the country (as Asian) and being an underrepresented minority (URM) within the context of higher education. Even in "Asian-majority" institutions (student-wise not faculty), the bureaucratic positing of Asians as an institutional "model majority" shrouds the place of Southeast Asian Americans, due to increased demand for Asian international scientists, students, and scholars (Bui, 2016).

Overall, it is hard to come by any reliable numbers for the number of SEAA faculty due to overly simplistic institutional categories and poor data collection (Wong et al., 2005). Beyond disaggregation of ethnicity/nationality, solutions to this problem could include allowing respondents to designate their own terminology of self-identification and pick more than one category. But too often, Asian Americans are frequently mixed with temporary residents from Asia. Unpacking the category of Asian might lead to loss of government funds, but the classification of minority-serving institutions can redress Southeast Asians as "invisible minorities" (Hafoka et al., 2020; Nguyen, 2020). In STEM fields, where most Asian faculty are most concentrated, half of all doctorates come from four countries alone (China, South Korea, India, and Taiwan), two-thirds of them arriving from overseas. Selective migration does little to change the cognitive construction of race. The hyper-selectivity of Chinese scientists extends to the Vietnamese, even though it is not true of the latter as they experience it (Tran et al., 2018). ${ }^{9}$ The racial construction produces institutional "amalgamation schemes" in the university that only reinforce social inequities (Sexton, 2008).

There comes a need to deconstruct categories while disaggregating them. Khmu, Cham, Malay, and Lao American experiences are distinct from those of Vietnamese and Filipinx Americans. The latter groups are better represented in academia more than others, due to their larger populations. Let us ask whether the big groups will advocate for smaller ones, especially given dwindling job positions. Potential antagonism among groups and the conflation of SEAA experiences by administrators in diversity reports are always present. The answer to this all remains mixed, something I experienced as the first chair of the Southeast Asian section/caucus for the Association of Asian American Studies. The collective fight for SEAA faculty still diminishes the smaller groups and benefits larger groups, so advocacy for SEAA academics must revamp the category of SEAA as it tries to promote it. How does one advocate for Karen faculty if a school has few Karen American students at a school? Such advocacy requires putting up the racialization of SEAA for closer scrutiny.

Educational systems and bodily schemas of value hark back to the Enlightenment, when white racial scientists designated the "Malays" or Malayan of Malacca (modern-day Malaysia) and Oceania as differing from the "Mongoloids." Johann Friedrich Blumenbach invented the five colored races based on anatomy (and mannerisms) still used widely now. He determined that there was a distinction between "brown" and "yellow" Asians, the former are Southeast Asians and Pacific Islanders, while the latter are Japanese and Chinese. In the contemporary world, yellow Asians now include South Koreans who have long been the colonized subjects of Japan but arose 
to cultural and economic prominence in the post-World War II period. Anthropologist Dredge Kang (2017) finds that there is now global demand for "white Asians" like Koreans. These cosmopolitan white Asians, he contends, are Japanese, Koreans, and even "tropical Chinese" settled throughout Southeast Asia. Many academics of Southeast Asian national origin like Singaporeans are also ethnic Chinese, and in academic fields where personal identity wraps closely around professional identity, they can be found in some hazy situations.

Exploring the Chinese SEAA in the academy addresses the racial and class hierarchy within both SEAA cultures and education. I learned this while interviewing literary scholar Weihsin Gui. As the child of a social worker mother and taxi driver-turned-engineer father, Gui came to the United States as an international student under scholarship. ${ }^{10}$ Despite minor challenges he faced in professional life, he recognizes his privilege coming from wealthy Singapore. In pursuing a $\mathrm{PhD}$ in America, he was discouraged from studying anything Southeast Asia-related, so he shifted focus to British literature, since Southeast Asia was never on the "academic radar." When I asked if he identifies as Asian American, he answers "no" due to not growing up here, cognizant as he is of the connotations of Southeast Asian (e.g., poor, Brown). ${ }^{11}$ Gui explains that he remains Singaporean (not Singaporean American), Southeast Asian rather than Southeast Asian American. ${ }^{12}$ Gui's sensibility accords with writer Shirley Geok-lin Lim (1997), who mentions how she was demeaned in the U.S. academy as a Chinese-Malaysian American, and as a Chinese exile from Malaysia. Like Lim, Gui toggles between intellectual/cultural spaces, a transnational negotiation which differs from Chinese-Vietnamese, Chinese-Thai, or Chinese-Burmese scholars. A big conundrum is the scholar that bears a Chinese surname, who might identify as SEAA out of pressure for more "diversity" or conversely take on a Chinese or general "East Asian" identification out of convenience. Ethnicity and race remain bound up with class.

Class stands as an issue mostly obfuscated, especially since the vast majority of working academics are drawn from professional families (National Science Foundation, 2018). ${ }^{13}$ Southeast Asian Americans who are poor might make it to college, but many do not reach graduate school. For those students, they are touted as the next model minority. Well-intentioned educators then exonerate our public education for failing students of color "by exalting Southeast Asians refugee children's educational attainments" (Cacho, 2012, p. 78). ${ }^{14}$ This modicum of success must be met with caution. One quantitative study by Takei et al. (2013) found that Filipinx, Vietnamese, and Thai have slightly higher than average educational levels than whites, due to recent selective migration. But Khmer, Hmong, and Laotians hold significantly lower odds of attaining education. ${ }^{15}$ While Vietnamese and Filipinx achieve higher than average rates, they do not excel at the same level for postgraduate studies, a key indicator of upward mobility or elite social status. Though considered the model minority among Southeast Asians, Vietnamese Americans are sometimes compared to Chinese (Lee \& Zhou 2015). But Vietnamese do not head into graduate programs in the same numbers as Chinese and other Northeast Asians. This discrepancy is reflected in a 2017 American community survey that found Vietnamese who obtain a graduate or professional degree at $9.7 \%$. Beyond sorting through the data, what we need are alternative frames.

Not all Southeast Asian migrants can claim poor working-class status since political revolutions also drove educated Southeast Asian elites to flee their countries. As Asian American historian Dorothy Fujita-Rony (2020) observes in her book The Memorykeepers, a U.S.-backed rightwing dictatorship propelled her educated family to settle in the United States. Instead of thinking of the Ivory Tower as a bounded silo, the third generation "Yalie" (graduate of Yale University) wants us to consider the ways the modern-day global university finds roots in the sprouting nodes and circuits of the Cold War knowledge economy. The professional trajectory of 
multiple generations of Indonesian academics is yoked to U.S. interventionism abroad. Elaboration of this insight exceeds the scope of this article but remains crucial for dissecting the "inter-empire" of education. ${ }^{16}$ Fujita-Rony's study emphasized women and feminized subjects as those people who hold the key to unlocking the gendered structures of the academic-military-industrial complex.

The "ethnic minority" from Southeast Asia struggles on many levels, not least of which being subordinated to ethnic majorities. Davorn Sisavath, the first Khmu person to receive a PhD in the United States, must contend with being minority (Khmu) within a minority (Laotian) within another minority (Southeast Asian) within a racial minority (Asian American). In my personal interview with Dr. Sisavath, she told me she was the lone "Laotian" scholar at her university, whose Khmu clan name was actually "Laotianized" or converted in the refugee camp. At her school, she holds responsibility as a spokesperson for all Laotians, even though she is not ethnically Laotian and the Lao Luom (the majority people of the homeland) historically view her hilltribe group as lower-class servants or slaves $(K h a)$. Sometimes other hilltribe ethnic minorities do not give her the respect of a professor. Despite being asked to, one Hmong American male student willfully refused to address her as "Professor" or "Doctor" (though he would do so for white male instructors). This microaggression can be attributed to sexism, classism, and racism. Laotian, Hmong, and Khmu female faculty are few, but their paucity in the academy should not reflect a diminutive social status - an issue which I expand on in the following section.

\section{Intersectionality: Gender and Ethnicity}

This section on intersectionality builds upon the previous on racial discrimination and class oppression to consider gender, sexuality, patriarchy, ethnicity, and Indigeneity. What is often left out of discussions of class, race, and nation are precisely those factors that marginalize the experience of women and ethnic minorities. For example, Vietnamese-speaking Kinh people are synonymously "Vietnamese," but that national category engulfs ethnic minorities like Khmu, Lu Mien, E De, Tai Lue, Miao, Churu, and the Cham. While pursuing her doctorate in ethnic studies, Cham American scholar Julie Thi Underhill (2014) recounts a story in which her Vietnamese language college instructor was shocked that her people, who are Indigenous to southern Vietnam, were still alive and had not all died off. The $\mathrm{PhD}$ candidate retorted with, "You didn't kill us all, you know." Ignorance of the Champa Kingdom and its colonization translates into a kind of "epistemic violence that forgets the maltreatment of Cham by ethnic Vietnamese people." 17 While this case appears as a simple case of racism, it involves a younger (queer) woman without a terminal degree opposing an older male straight teacher in a position of authority. Here, we can better define an intersectional framework in terms of the ways heteropatriarchy and misogyny thwart women in the professoriate. A significant number of the stories shared by self-identified SEAA women went deep into gendered working environments, academic sexual politics, and women's invisible labor. These stories refract glaring numbers: Asian women achieve terminal doctoral degrees at two-thirds the level of Asian men (Chen \& Hune, 2011).

An analysis of gender as it intersects ethnicity deepens the extant scholarship on academic women of color. Farrah Aziz-Shaw is of an ethnic minority group, one whose family fled genocide in Cambodia and Vietnam, where they are Indigneous. ${ }^{18}$ The first-generation Muslim scholar does not fit in any box, as I discovered in my online interview with her, since her people are not counted by the U.S. Census (she picks "Other"). The recent PhD did not know any professors in her

community, but she contradicted social expectations to raise a family after high school. "Everyone 
expected me to finish high school and have babies, but I didn't want that." ${ }^{19}$ Like so many SEAA youth, she pursued higher education administration, a fast-track to a middle-class lifestyle. AzizShaw left this staff job after a few years to chase a doctorate, after noticing that no one else was going to study her community in academia unless she did. In graduate school, she found white and Japanese American administrators did not care much for Southeast Asians, papering over their requests for more mentoring support. Yet, it was her Native Hawaiian/Kanaka Maori advisor, whom Aziz-Shaw attributes with helping her finish the dissertation. In a time of much scrutiny of Asian colonial settlers in places the Hawai'i, the displaced SEAA Indigenous/ethnic minority refugee occupies a vexing positionality, something that goes beyond the purview of this limited study.

Symbolic violence bleeds into material violence. While full-time tenured positions are in free fall, these worries remain acute for SEAA women. Interestingly, political scientist Caroline Kieu-Linh Valverde was denied tenure within an all-Asian ethnic studies department. ${ }^{20}$ Occurring parallel to the tenure denial of another prominent Vietnamese American female scholar in the country, Valverde's tenure denial was ironically overturned by white administrators. What can be gleamed from this case is that there are no totally safe spaces within academe, even within so called "minority-majority" spaces. Valverde must now seek full professorship in the same department that denied her tenure. Let us consider Valverde's writings.

As widely anthologized, Valverde's (2013) tenure battle was a literal life-and-death struggle. ${ }^{21}$ In the volume Fight the Tower, the political scientist described "the killing machine" of academia, comprised of mental assaults, spiritual death, sexual harassment, and daily traumas that impinge on the health of SEAA women (Valverde et al., 2019). Such issues take shape as a form of emotional labor that puts a weight on women's career advancement, a gendered expectation that discounts their major intellectual contributions and hinders their academic pathway and development of "academic families" (Castellanos \& Jones, 2003). A more complex situation arises for lesbians, asexuals, bisexuals, pansexuals, transwomen, and gender fluid/nonbinary people. Future studies of SEAA should consider gender non-conforming and sexual minority SEAA scholars. A lack of knowledge about intersectionality prevents knowing what is needed to truly diversify faculty bodies and expand social mobility.

The content of Valverde's public testimony resonates with my private interview with another woman of color academic. A newly minted $\mathrm{PhD}$ on the job market (who chose anonymity) expressed their harrowing time in graduate school, as the only visible Brown woman in a topranked humanities program that wanted "colored copies or facsimiles of white scholars but not actual people of color academics." 22 A scholar of the Ilocano diaspora, she was asked to teach Latinx studies, due to confusion from all the people colonized by Spain. When the post-doctorate was presented first with a tenure-track position for Asian studies, she turned it down because they were expected to teach mostly about Northeast Asians and not encouraged to work on Southeast Asians. The scholar explains, "I know I am Asian American, but I would prefer to say Southeast Asian, because when people imagine Asians, I'm not it." She attributes her problems to not just race, but the fact that people see a dark-skinned woman of color who is not afraid to speak up in the office or in research. As ethnic studies scholar Loan Dao echoes, scholarship "is about my whole being in the world, something that cannot be separated from my research or social movements or activism." 23

SEAA women faculty encounter enormous barriers in increasing their numbers, but the brutal fight for positions and tenure coincides with the constant questioning of who are Southeast Asian/Americans, where do they belong in a system that was not made for "them." The 
professoriate comprises a form of "cultural class" that may or may not link up with one's familial socioeconomic status and guardians' educational background. Cultural linguist Kanjana Thepboriruk's mother came to pursue college in the United States. However, her mother dropped out of school to run a threadbare restaurant like so many Thai immigrants. As Thepboriruk admitted to me in our interview, she grew up financially strapped but was never "emotionally and mentally poor;" she adds, "I was socially and culturally rich." ${ }^{24}$ My informant reflects that had it not been meeting a Thai faculty member as an undergrad, the language specialist might not have found her way though/in/around the academy. Locating only one other Thai American grad student in the entire country, Thepboriuk shared archival sources with her co-ethnic peer, despite their completely different fields of study. ${ }^{25}$

As a professor, she struggles to find a Thai student to work with as a doctoral advisee, as some Thai Americans finish at the master's level (often an MBA) rarely continuing onto the PhD. She attributes this lack of doctoral aspiration to the same immigrant mentality to acquire quick money as her mother to support family. When I asked Thepboriruk what makes her Southeast Asian American, she states it is because she is not a "CJK" (Chinese, Japanese, Korean). This rhetorical quip suggests SEAA are overshadowed by notable Asian groups. As a woman of color, she credits her resistance to cultural patriarchy as one main reason for her academic success. But how do patriarchal norms stretch beyond the community context to include academia?

Without prompting, patriarchy was often discussed by all my female interviewees as a significant problem in their lives. They mention both cultural patriarchy and academic patriarchy, even if they could not always make a direct connection between them (or treated education as liberation from cultural tradition). All the women I talked to brought up sexism as an issue in their personal and professional lives, but suggested their strong personalities led them to defy expectations. In their jobs, they faced constant opposition to their abilities, which they attribute to being Asian women and more specifically Southeast Asian women. We can ask if there is a form of mutual reinforcement. How does a SEAA woman navigate male-dominated communities differently than universities with a top-down structure that views its "feminized" teachers as disposable invisible workers? Patriarchy operates within personal interactions to reveal how "embodied difference" works through and across structures of domination.

Intersectionality here emerges as more than a random convergence of multiple identities/oppressions. It is important here to define intersectionality to make more explicit how gender, patriarchy, and misogyny impact SEAA women in the professoriate. Taking up the term coined by critical legal scholar Kimberlé Williams Crenshaw (1990), Asian American academics consider academic spaces as shaped by patriarchal norms on top of being racialized and classbased spaces (Harris \& Patton, 2019; Museus \& Griffin, 2011). Intersectionality describes a robust concept that complements an anti-racist and comparative approach, highlighting aspects of a person's identities produced from different combined modes of discrimination and privilege. Issues found in academic spaces therefore pile on and converge with those in community spaces.

This observation finds corroboration by Mai See Thao, whom I interviewed remotely. The interdisciplinary public health expert says Hmong women indeed "do it all" under patriarchal family duties. When I spoke to her, Thao had just finished her postdoctoral position and moved into a new job as the only Hmong/Southeast Asian faculty member at her university. She shared some painful past experiences as a graduate student meeting faculty, who would introduce their white mentees to other scholars to build professional networks. They ignored her, taking the firstgeneration scholar as another "hardworking" Asian. At the same time, SEAA stereotypes crept up as some registered shock that a Hmong mother with multiple kids managed to finish a doctorate. 
Despite having a mother with no years of formal schooling and a teacher father with elementary school education, Thao deems this parental educational background as a source of resilience and grit. The mother of two explains her professional struggles now revolve more around representing to academia the interests of outside communities (Somali, Latinx, Hmong) poached for research. The anthropologist considers the lumping of all Asians into one group a form of systemic racism that matches the racism found in extractive data-collection. She told me four recent Hmong studies positions in the Midwest had opened after racist campus incidents, joking "racism is what gives us jobs!" That liberal education institutions feel compelled to produce said jobs only after such incidents reveal as much about how universities manage race, but also gender and class in terms of the women of color who they regularly tap to conduct or handle diversity work.

The successes of scholars like Thao inspire the rising numbers of Hmong women that follow in their footsteps, such as doctoral candidate Chong Moua whom I also interviewed. The self-proclaimed "jungle Asian" who grew up in public housing finds academic work "limiting if it does not reach or help the community." "26 Moua contends that only when academia matters to the community will the Hmong escape the "model minority maze" (Lee et al., 2017). This insight flips the belief that the Hmong community is only legible when they can assimilate into higher education.

A stronger network of "femtors" or female mentors remains essential to increasing the next generation of SEAA academics. Public writings about and by Hmong American women public speak to this fact. According to Dia Cha (2016), the first Hmong American and woman to receive a PhD in the United States, Southeast Asians and the Hmong pose a challenge to talking about race, nation, and war. ${ }^{27}$ As well, Chia Youyee Vang, the first Hmong American to reach the rank of full professor, created an interdisciplinary Hmong Diaspora Studies program at her school that is inclusive of other people of color. C. Y. Vang (2016) defines SEAA communities as "products of war. Forced displacement is one of many reasons why Hmong Americans are the most impoverished Asian Americans with many adults lacking education" (p. 76). Mai Na Lee, the first Hmong American to earn a doctorate in history, believes her purpose is to heal bodies and "focus on the spiritual aspects of my own people . . . because if I don't care enough to do it, nobody else is going to" (quoted in Wisness, 2008). Building a strong academic pathway opens the doors for others and breaks gender expectations.

Gender means more than women but also includes other masculinities and men. I uncovered this point in my interview with Steve Arounsack, an anthropology professor, who on the side is a filmmaker and was a consultant for Disney's first Southeast Asian-themed movie. As a child of a teacher-mother and physician-father, he considers his life fortunate as a college mentor who can "shine a beacon of light and hope" to his mostly Chicano/a and Mexican American students; he does not encounter SEAA students in the same numbers. ${ }^{28}$ One can think of the Laotian community as small, he says, but that smallness makes them special. Arounsack learned to "Laotianize" the various professional worlds he inhabits (while working as a proxy for other marginalized communities). In this context, Laotianization might mean taking what is viewed as minor or diminutive (like the country of Laos), and amplifying its powers or reach. While Lao and Hmong refugees came in almost similar numbers, Arounsack notes the stunning successes of the Hmong in American higher education, due mostly to the efforts of women. Such efforts are personal and collective, insofar as academic Hmong women contend with hegemonic cultural imaginaries and social formations that affect multiple populations, a theme to which I turn to in the next section on comparative approaches to employment and mentoring. 


\section{Comparative Studies: Employment and Mentoring}

This last section lays out the obstacles to student-faculty interaction as it relates with and across groups. A handful of studies attuned to racialized class characterize Southeast Asians as underrepresented "faculty of color" in the same vein as Latinx, American Indians, and African Americans (Nguyen-Lam, 2002). They address similarity in these groups' hyper-racialization and criminalization (Lo, 2018). Researchers found that "the personal experiences of Southeast Asian American teacher candidates and faculty in the [education] programs reflected a discrepancy between the written institutional commitment to diurnal diversity in the recruitment, preparation, and retention process of diverse teacher candidates" (Whetsel-Ribeau, 2007). In other words, inattention to SEAA college instructors demonstrates a lacunae or failure of diversity policies. Education scholar Malaphone Phommasa (2016) discovered that an overwhelming number of SEAA students (up to 97\%) have never interacted with SEAA faculty outside of Asian American Studies or language classes. The great majority of students recognized a lack of faculty contributed to their academic isolation and social loneliness. ${ }^{29}$

Greater SEAA faculty presence would improve in campus racial climate and cultural validation, allowing for greater community engagement (Vang, 2018). Living in the shadows of an "overrepresentation" of Asian men, SEAA male students drop out in large numbers, which does not bode well for the production of Southeast Asian professors. ${ }^{30}$ College instructors Andrew Cho and Sophang Men (2019) document their "racial battle fatigue," stemming from students, staff, faculty, and administrators never recognizing their academic expertise in anything non-Asian. This racial targeting occurs even when one changed his Buddhist Burmese name to a more "Americansounding" Christian name to move ahead. Colleagues always assumed the men were Chinese or Korean, looking perplexed when they admitted that they were from lesser-known countries like Cambodia or Burma/Myanmar. Given the quandary of SEAA males, they emphasize maleidentified students need more SEAA male role models (Xiong et al., 2020).

The representation of Southeast Asian American college faculty dovetails with those of other historically underrepresented racialized groups. As Chicano/a and Latinx studies professor Glenda Flores illustrates, Latina teachers as "cultural guardians" are also compelled to mentor poor Vietnamese and Cambodian students who occupy spaces with Latinx students. ${ }^{31}$ In my email interview with Flores, she dissects the SEAA issue in a straightforward manner: "It is of utmost importance to have more SEA American faculty in academia because they provide different perspectives, will pose different questions, and may have different ways of understanding interactions." $" 32$

Flores recognizes the racial ordering among Asians and how Southeast Asians are what sociologist Patricia Hill Collins characterizes as "outsiders-within." The fight for Southeast Asian faculty, she contends, falls back into the larger struggle to include Latinx and brown people within what Flores calls "whitestream" or white mainstream professions.

While my focus thus far has been on professors with full-time tenure-track jobs, I must also take into consideration the working lives of lecturers (full and part-time), visiting/non-regular professors on temporary contracts. Today, these individuals make up two-thirds of all college instruction and academic positions not eligible for tenure (Griffey, 2016). The "leaky pipeline" for SEAA academics starts in this murky terrain, one full of horror stories as much as tales of triumph. From my own personal networks, I recount stories of one lecturer, who had been assigned with bringing majors to a program, but when full-time teaching positions opened, they were given to a Northeast Asian or white person. Another adjunct became a faculty advisor to a Southeast Asian 
student group (something outside normal job duties), even though tenure-track professors were not asked to do this type of mentoring.

Southeast Asian American lecturers often mentor students in ways that go unrecognized, something I learned more about after interviewing Seng Vang. As the oldest of 13 siblings, Vang works as a lecturer of writing at two different universities, commuting hours between them. Insofar as his parents did not finish elementary school, he never considered pursuing a $\mathrm{PhD}$, except after being personally mentored by a Hmong professor. The contract instructor believes Hmong adolescents like other SEAA males are tracked into crime, puts in harm's way within the U.S. "war on crime." This domestic war connects back to the "secret war" in Laos, which he observes ironically afforded "the Hmong educational and economic opportunities for the first time." This politicized the community to fight for what they wanted later as refugees in the United States: Higher education. Yet, Vang notices that many successful Hmong youth end up as college support staff or counselors. Few are tenured faculty, where most power resides in the university. Almost all the Asian faculty who he notices on his campuses are internationals; and while they do contribute to institutions in some way, he does not see them helping transform the academic culture in the same way as poor Southeast Asian Americans who grew up here and who struggled could.

Vang's graduate school education became derailed by the post-2008 recession and its impacts on his working-class family, economic repercussions from which he never fully recovered. Despite his struggles, Seng seeks to empower all his URM students academically to overcome the system. For him, "it's a struggle every day to fight to stay . . . but then again if I didn't fight and left, the students would lose out." There are many SEAA academics who are on the job market or ascending the steps of graduate school. The potential of being pushed out or sidelined are enormous for SEAA, men of color, and the working-poor. A comparative approach sheds light on the multiplex facets of academic life and beyond.

"I have deep trauma, brother," Peter Keo told me during an interview. ${ }^{33}$ Despite his family's low education, the Cambodian American went on to attain a doctorate, where his research indicates how the lack of disaggregation of SEAA males from all "Asian men" reinforces cultural essentialization (Keo \& Noguera, 2018). His educational accomplishments are not minor, considering the Khmer Rouge killed off the most educated Cambodians under its reign of terror, and most refugees came only with an elementary school education or less. Though steeped in matters of social inequity, the education specialist still deals with the same "imposter syndrome" that plagues so many of his highly educated brethren, even while recognizing the structures of power undergirding that syndrome. ${ }^{34}$ Throughout his career, Keo finds so many educators and policymakers are unwilling to recognize the importance of Southeast Asians, especially as they relate to Latinx and African Americans. As he puts it, "we don't matter for racial equity." Throughout his long career, he met no Khmerican faculty who could mentor or guide him, which planted confusion about his true vocational path. Keo wonders if he should (or could) have become a professor, even if today he obtains success directing a university center. At present, Keo does educational consulting on the side to support all communities affected by historical violence.

As a child of the diaspora, Keo balances his work with spiritual practices to overcome the intergenerational trauma of genocide in Cambodia and the violence of structural racism in the United States. The trauma formation of "refugee subjecthood" blends into the microaggressions that so many Khmer Americans endure in school, preventing them from achieving (Kwan, 2020). Insofar as the children of Cambodian refugees are the "collateral damage" of war, they remain culturally "unsettled" (Tang, 2015). Their battles for survival in the academy epitomize a war to live and thrive on their own terms. 
This fight for survival in academia is sometimes pedagogical. An increase in the presence of SEAA professors must be equally matched with courses on Southeast Asian America, where the instructor's cultural background can stand-in as a larger pedagogical strategy to enable CHLV (Cambodian, Hmong, Lao, and Vietnamese) to pursue higher education (Kiang, 2008). In the "pedagogies of life and death," education researcher Peter Kiang avers these specific courses attract other marginalized students with refugee backgrounds from Sudan, the Republic of the Congo, and Haiti (Kiang, 1997). ${ }^{35}$ But who will teach these courses if the professors are not there? What classes are made available in the first place for SEAA?

The institutional absence of SEAA faculty and classes loops into cultural gatekeeping. Amid lambasting his community for being sometimes antithetical to intellectual pursuits, sociologist Anthony Ocampo calls out his discipline for not mentoring the next generation of Pilipino/a/x scholars: "Professors often can't see the importance of studying the Filipino American experience, and as a result, they aren't lining up to mentor us" (Nadal, 2016). An abiding sense of social and disciplinary "fit" thwarts the hiring and retention of Filipinx faculty, worsening "elusive belonging" in the Ivory Tower, especially for women faculty (Buenavista, 2013; Vo, 2012).

As pointed out by some of my interviewees, SEAA academics are habitually rejected by departments that claim to look for Asian-identified scholars with a "broader" emphasis (code for China or Japan specialists). The Southeast Asian American experience does not always find adequate representation due to categorical racism, but also the lack of understanding between SEAA and other underrepresented groups. Resolving these problems might result in the overhaul of not only general academic curricula, but also ethnic studies and disciplines presenting itself as the vanguard of the "Other." Otherness needs specificity when it is researched. More studies of Southeast Asian American academics are sorely needed to change ingrained thinking and public policy.

\section{Conclusion: Policy and Positionality}

Broadening the definition of SEAA in my study, I explain why this group has been underrepresented in academia and how members view their socio-educational realities. My hope is that scholars, students, and casual readers will ask anew about the "Southeast Asian American academic." I hope they use the discussion to consider the issues I introduced about rank, class, race, gender, sexuality, nationality, immigration status, ethnicity, and Indigeneity. Here, I emphasized the legacies of history, the mutability/durability of social categories, the entrenched nature of institutions, and the political agency of groups. The lack of awareness about the social positioning of SEAA population and other groups led to initial resistance to the federal designation of Asian American and Native American Pacific Islander serving institutions or AANAPISI (Park \& Teranishi, 2008). Further work on SEAA academics would inspire such initiatives that can potentially address systemic deficiencies. One compelling objective of the piece is to identify the SEAA academic "problem" as one major part of the compounded issues of DEI (Diversity, Equity, and Inclusion). As many scholars have grappled with DEI, I do not dwell on it much here but draw upon their work to point toward future directions for policy or research.

Throughout this article, I make a clear argument for why this study is necessary as it builds a critical examination of SEAA educators/instructors in the U.S. academe, which aims for more empirical data even as it deconstructs what already exists. This dual purpose drives my focus on discursive aspects like identity formation, cultural frames, and social taxonomies. As a researcher and member of the community, I recognize both the distinctness and capaciousness of the SEAA 
category. Southeast Asian Americans continue to puzzle educators even as they wrestle with how to diversify the professoriate in the twenty-first century.

The personal is professional. I want to anchor my positionality to justify my study and approach. At my public university where Asian/American students are the majority, I am the first Vietnamese and only SEAA professor in the school of social sciences. Almost by default of being SEAA, I am the sole first-generation Asian faculty member in the school, whose parents never attended college. This sits on top of the fact that I was hired as the only "first-gen" faculty member in my department. I would not be where I am today had it not been for meeting SEAA faculty invested in but burdened with student mentoring. ${ }^{36}$ Their advice to me as an undergraduate on how to navigate academia was shaped by their own positionalities as Southeast Asian women of color. Their struggles with finding a job, obtaining tenure, dealing with racist sexist colleagues, and getting to "full" professor resonated with me as a working-poor man of color. Their wisdom and experience shape my world view as a non-normative subject in institutions not made for people like "us." Indeed, my land grant/grab university was built on the ancestral lands of the Acjachemen and Tongva people who do not hold any representation in the faculty at all. ${ }^{37}$

Despite the public notoriety of the Vietnam War, this major historic event for the United States does not necessarily induce any major need to look for "native informants." At my home institution (located in the area with the largest number of Vietnamese people in the country and outside Vietnam), the first ever advertised job for a Vietnam specialist came down to two finalists, a white man and a Vietnamese woman with the position going to the former. The female candidate went on to succeed in another institution, while the former voluntarily left his job to avoid missing the mark of tenure. There is no way to track all the "missed opportunities" in hiring, cloaked in the mystified language of meritocracy. We do not know everything, as there exists a dearth of Southeast Asian American faculty in the U.S. academy and data that tracks their matriculation. With their tokenization and concentration within fields like Asian American studies or education, and a lack of data disaggregation from all Asian faculty in academia-SEAA are a barely visible social group in an education system bent on maintaining institutional inequalities.

Future directions will expand upon this study to incorporate a more anti-imperialist perspective. Such a critique is crucial, due to the expansive influence of the Asian model minority myth as a circulating Cold War-derived global discourse. Public advocacy that draws on antiimperialist critical race theory will "highlight the systemic contexts that differentially shape the conditions of diverse ethnic groups within them" (Yi et al., 2020, p. 545). In the process of contextualizing the experiences of SEAA faculty and interweaving narratives, many things could become lost, such as connections to settler colonialism and Pacifica/First Nations/Indigenous sovereignty movements. Subsequent studies on SEAA academics should connect all these threads.

Southeast Asian academics encounter numerous landmines related to academic motivation, admissions, acculturation, attainment, socialization, graduation, hiring, tenure, and reaching full professorship. Hailing SEAA as the anti-model minority or even a new model minority overlooks the community's very multiplicity and complexity. Perhaps, SEAA academics do not rise to significant numbers to effect or affect public policy on a massive scale, but hopefully this study provides a sense of the power that we hold despite our size or standing.

But increasing the numbers is not enough, personal stories and public testimonies are just as vital. It behooves researchers interested in advancing Southeast Asian Americans in higher education to also examine the stories of professors and not just those of students. They should adopt an anti-racist, comparative, and intersectional analysis to not neglect internal community dynamics or intergroup conflicts. This reframing involves revealing struggles and experiences of 
SEAA professional teachers, which will help us build a university that is truly inclusive and welcoming to all.

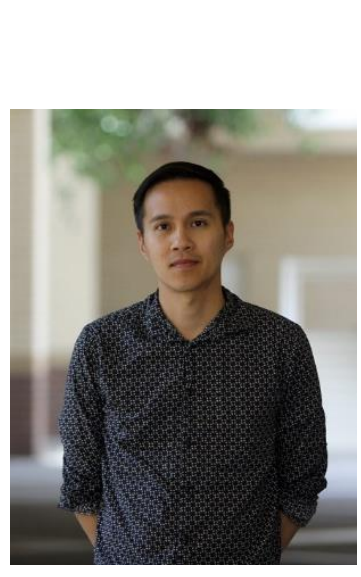

\section{About the Author}

Long T. Bui is an associate professor of global and international studies at the University of California Irvine. His research focuses on Vietnamese/American cultural politics and education. He is the author of Returns of war: South Vietnam and the price of refugee memory (New York University Press, 2018).

\section{Notes}

1. Southeast Asian's meaning depends on the individual and the socio-historical-political factors that comprise their identification. SEAA is a geographical, personal, and political designation that depends on war experiences (refugees), colonialism/imperialism (Dutch Indies, French Indochina), and resettlement/migration (Chinese merchants/expats).

2. Despite outlining these clear differences, the authors utilize the hybrid descriptor of "East/Southeast Asian" throughout the study. The study also found that Asian men still earned less than non-Hispanic white men, despite the former's greater educational attainment.

3. I had previously taught at a private college that had an autonomous College of East Asian Studies, the main objective being to attract Northeast Asian capital, human and financial. There was no Asian American studies curriculum, and I was hired as a visiting professor in a position created due to student protests around this issue. At my next school, the school newspaper announced they hired six Asian professors to showcase diversity. However, five of these faculty had come straight from China and I was the lone U.S.-born Asian American and only Southeast Asian American on the entire campus. Again, I had taken on the task of assisting students once again to fight for Asian American studies, which students saw as improving Asian faculty diversity, something more inclusive than traditional area studies. When I met with the president to discuss the campaign, she had asked me about this "Asian studies" problem (the school already has a department), even though students have been protesting for years for Asian American Studies. This total lack of awareness is a form of prejudice. Students came only to me to lead the fight for Asian American Studies, since activists found the other Asian faculty as not as fully invested in the antiracist Asian American cause, although this is changing with increased awareness of racism.

4. The diverse non-tenure track group is beyond the scope of this study, but one that informs my discussion, since many full-time tenured faculty members had to first work in temporary positions, given the state of academic hiring.

5. To be sure, there is an economic bottleneck or hourglass effect within Korean and Han

Chinese communities that includes the extremely wealthy and those from low SES. Future 
research can go into how many academics come from deprived or under-resourced backgrounds operate within their respective groups, even though it is hard to measure socioeconomic status for faculty.

6. At my campus, students are $13 \%$ white (that include MENA/SWANA people), but white faculty are close to $50 \%$.

7. Concentrated mainly in STEM (Science, Technology, Engineering, Mathematics), many of them come to the country as adults and might experience racism as an adult for the first time on top of dealing with visa woes. Yet, the percentage numbers of postgraduates for U.S.-born and foreign-born Northeast Asians are nearly identical, which suggest these highly educated Asian immigrants are merging with their American co-ethnics.

8. Not only is northern-ness of East Asia (and Asian in general) hidden and naturalized in the American academy, but Southeast Asia appears as an outlier or exotic cousin to the former. Northeast Asia almost never means scholars coming from North Korea, Tibet, Mongolia, and the aboriginal communities of China, Japan, and Taiwan. So, while I employ Northeast Asia, I recognize its contested nature as well.

9. While the authors of the longitudinal study suggest those spillover benefits might become a self-fulfilling prophesy in forming success-oriented cultures and racial mobility, they do not mark differences between Vietnamese and Chinese communities. Yet, they recognize how non-Chinese Asians still lump together Indians and Koreans with Cambodians and Laotians.

10. He found his calling after professors, seeing his academic potential, suggested he go on to grad school. He had wanted to be a high school teacher, but colleagues said dealing with Singapore's notorious educational and political bureaucracy would be a headache. Singapore's push for global rankings and stature fuels demand for foreign scholars that are not-Singaporean and global-oriented research that discourages local studies of Singapore. Interview on Zoom July 21, 2020.

11. As someone who came to the United States as an adult, he might mentor first-generation Asian immigrant students, but remains illegible to many U.S.-born or second-generation Asian American students who view as him as "foreign."

12. He helped lead the Southeast Asia and Southeast Asian diaspora section of the Modern Language Association (MLA), the largest humanities association, and it fell under the Asian American section since the Asia section focused more on geopolitical areas and not diasporic/U.S. minority communities. As the director of a Southeast Asian studies center on his campus, he seeks to provincialize the United States as the locus of Southeast Asian area and diaspora studies to also include Australasia.

13. In 2018, 44\% of PhDs had parents who had a postgraduate degree, while $83 \%$ had some college. Meanwhile, Asian non-citizens made up $77 \%$ of all Asians getting a PhD, while for all other racial groups, the vast majority of doctorates go to U.S. citizens. A child of professors is more than 25 times likely to be a professor.

14. Like many low-income migrant communities, "post-Vietnam" refugees were thrown into a variety of places, from working-poor ethnic immigrant enclaves and/or dispersed into alienating rural/suburban white neighborhoods. As Lisa Cacho makes evident, many Southeast Asian Americans found a way to leave the "ghettos," contributing to white/Asian flight from the city. This "refugee exceptionalism" marks them off from "deviant" pathologized African Americans. 
15. Looking at immigrant Southeast Asians versus U.S.-born ones, the PI's subvert prevailing wisdom and the intellectual status quo (controlling for the "carry-over" effects of lesseducated migrant parents). Notable are Vietnamese, who are twice as likely as whites to obtain a baccalaureate degree, even though most are children of refugees coming from relatively humble socioeconomic origins. High levels of educational attainment among non-immigrant Vietnamese pushed researchers to argue that we should avoid making broad statements like Vietnamese and other Southeast Asian refugees "languish at the bottom of the economic pyramid, along with blacks."

16. In the first monograph on Indonesian Americans, one that discounts the notion that her people (Toba Batak) are too small in numbers to count for study (and women's stories do not matter), the historian documents her parents coming to study at Yale University (her own alma mater) under the auspices of studying Vietnamese language at the height of the Second Indochina War.

17. Underhill was asked to teach lectures on the Cham by her Vietnamese teacher, but this type of academic opportunity also puts burdens on the younger academics to constantly teach their seniors.

18. Interview with Aziz-Shaw on August 25, 2020. Pseudonym preferred.

19. Her father wanted her to go to a Muslim university in Malaysia, but she stayed in the United States due to the greater opportunities and status this afforded.

20. This bitter tenure battle was documented in public writings that reflect beyond the Asianwhite binary (although some would argue whiteness structures the entire U.S. academy). As one of two Southeast Asian faculty, the mixed-race scholar found herself in a nearly all Northeast Asian-dominated program at a school with majority Southeast Asian mostly Hmong student population.

21. The expecting mother died and had been clinically pronounced dead for over an hour and had to be resuscitated from the shock and agony of the whole ordeal, which included losing an unborn child. The ghosts of academia are plenty, and SEAA women are often apparitions of whose mind and body counts.

22. Interview with anonymous source on August 26, 2020.

23. Interview with Dao on September 4, 2020.

24. Interview with Thepboriruk on July 13, 2020.

25. To showcase this inclusiveness, ChiLa3 (Chicano/a Latino/a Association for an Autonomous Anthropology) includes Southeast Asian members along with African Americans, Native Americans, and other marginalized groups in the field.

26. Interview with Moua on August 12, 2020. She had originally chosen a computer science major but struggled to keep up with fellow CS students who had their own private computers, when she had to do work on computers in school computer labs. She eventually got into history to prove that Hmong history is part of U.S. history but finds that American historians do not get why the Hmong matter to America.

27. Dr. Yang Dao was the first Hmong to receive a PhD at the Sorbonne in Paris. The French had colonized Laos, which opened up such pathways for international study. In the war for economic-racial justice in the United States, Hmong Americans are complicated subjects as when police officer Tou Thao stood by while his white counterpart kneeled on the neck of George Floyd, whose death ignited mass protests. The fight for working-poor Hmong to be known outside such hot flashpoints are vital.

28. Interview with Arounsack on August 5, 2020. 
29. This which is why it is important to have professional staff and administrators like Latana Thaviseth, who currently directs an Asian American Activities Center but was formerly the recruitment coordinator for the Southeast Asian community at another school (she was relieved of this "temporary" position, a controversial top-down decision protested by SEAA faculty and students). She attributes her professional success to not being subjected to gender roles so common in many SEA communities (Phetmixay, 2019).

30. Even in teaching universities, they do not have a significant participation gap, but a significant persistence gap, the worst of any group examined (Yang, 2017). This lack of attention adds to the fact that the Hmong have the highest poverty and lowest education attainment of any ethnic group in California.

31. Flores (2017) in her study, Latina teachers studied Latina teachers working in Asianmajority schools. Flores distinguishes the Chinese from the Vietnamese and Cambodians, acknowledging that Latinx teachers are mentors to working-class Southeast Asians, giving an example of one dark-skinned Vietnamese student struggling academically who did not wish to be identified as "Asian" for that reason.

32. Email questionnaire with Flores on July 13, 2020.

33. Interview with Keo on August 31, 2020.

34. Despite many accomplishments, the independent scholar is haunted by the burning question of alternative realities, wondering if he should have gone the traditional route to become a tenure-track professor.

35. A student in a Cambodian American seminar was inspired to develop future courses related to Somali Americans.

36. They are the awesome professors Linda Trinh Vo and Dorothy Fujita-Rony in undergrad and Yen Le Espiritu in graduate school.

37. I began my employment tenure at the same time the school settled a case involving a Vietnamese American gay male denied tenure to a professor of chemical engineering and materials science. He accused the school of homophobia, despite recommendations for tenure by his department.

\section{References}

Bonilla-Silva, E. (2002). We are all Americans: Toward a new system of racial stratification in the U.S.A. Race and Society, 5(1), 85-101.

Borromeo, V. (2018). A phenomenological inquiry into the racialized experiences of Southeast Asian American community college students. [Doctoral dissertation, University of Denver]. ProQuest Dissertations \& Theses.

Buenavista, T. L. (2013). Pilipinos in the middle: Higher education and a sociocultural context of contradictions. In D. Maramba \& R. Bonus (Eds.), The "other" students: Filipino Americans, education and power (pp. 259-275). Information Age Publishing.

Bui, L. T., (2016). A better life? Asian Americans and the necropolitics of higher education. In E. Nada, D. Hernandez, J. Kim, S. Redmon, D. Rodriquez, \& S. See (Eds.), Critical ethnic studies: A reader (pp. 159-174). Duke University Press.

Cacho, L. (2012). Social death: Racialized rightlessness and the criminalization of the unprotected. New York University Press. 
Castellanos, J., \& Jones, L. (2003). The majority in the minority: Expanding the representation of Latina/o faculty, administrators and students in higher education. Stylus Publishing, LLC.

Cha, D. (2016). Interview with Mary Stucky [Interview]. Crossing East Archive. https://www.crossingeast.org/crossingeastarchive/category/programtranscripts/prog6/teahouse/

Chen, G. A., \& Buell, J. Y. (2018). Of models and myths: Asian (Americans) in STEM and the neoliberal racial project. Race Ethnicity and Education, 21(5), 607-625. https://doi.org/10.1080/13613324.2017.1377170

Chhuon, V., \& Hudley, C. (2008). Factors supporting Cambodian American students' successful adjustment into the university. Journal of College Student Development, 49(1), 15-30. https://doi.org/10.1353/csd.2008.0005

Cho, A., \& Men, S. (2019). Navigating weird comments, stereotypes, and microaggressions as Southeast Asian American faculty at a predominantly white community college. In N. Hartlep \& D. Ball (Eds.), Racial battle fatigue in faculty: Perspectives and lessons from higher education (pp. 57-69). Routledge.

Choy, C. C. (2003). Empire of care: Nursing and migration in Filipino-American history. Duke University Press.

Clutario, G. (2013). History of Filipino women and global migration. In E. Park \& X. Zhao (Eds.), Asian Americans: An Encyclopedia of Social, Cultural, Economic and Political History (pp. 424-448). ABC-CLIO.

Cousin, G. (2010). Positioning positionality: The reflexive turn. In M. Savin-Baden. \& C. H. Major (Eds.). New approaches to qualitative research: Wisdom and uncertainty (1st ed., pp. 9-18). Routledge. https://doi.org/10.4324/9780203849873.

Crenshaw, K. (1990). Mapping the margins: Intersectionality, identity politics, and violence against women of color. Stanford Law Review, 43(6), 1241-1299. https://doi.org/10.2307/1229039

Dao, L. T., \& Keo, P. T. (2020). "'Special issue editors' introduction': Voices from the field: Centering Southeast Asian Americans through policy, practice, and activism." Journal of Southeast Asian American Education and Advancement, 15(2), 1-10. https://doi.org/10.7771/2153-8999.1211

Espiritu, Y. (2014). Body counts: The Vietnam War and militarized refugees. University of California Press.

Finkelstein, M. J. (2010). Diversification in the academic workforce: The case of the U.S. and implications for Europe. European Review, 18(S1), S141-S156. https://doi.org/10.1017/S1062798709990366

Fujita-Rony, D. (2020). The memorykeepers: Gendered knowledges, empires, and Indonesian American history. Brill.

Flores, G. M. (2017). Latina teachers: Creating careers and guarding culture. New York University Press.

Gray, K. (2013). Aid and development in Taiwan, South Korea, and South Vietnam. WIDER Working Paper, 2013(85).

Griffey, T. (2016). Decline of tenure for higher education faculty: An introduction. The Labor and Working-Class History Association. http://www.lawcha.org/2016/09/02/declinetenure-higher-education-faculty-introduction/ 
Hafoka, I., Vaughn, K., Aina, I. \& Alcantar, C. (2020). The "invisible" minority: Finding a sense of belonging after imperialism, colonialism, and (im)migration for Native Hawaiian and Pacific Islanders in the United States. In R. Teranishi, B. Nguyen, C. Alcantar, \& E. Curammeng (Eds.), Measuring race: Why disaggregating data matters for addressing educational inequality (pp. 67-83). Teachers College Press.

Harris J. C., \& Patton L. D. (2019). Un/Doing Intersectionality through Higher Education Research. The Journal of Higher Education, 90(3), 347-372. http://doi.org/10.1080/00221546.2018.1536936

Holcombe, C. (2017). A history of East Asia. Cambridge University Press.

Hoogervorst, T. (2012). Some reflections on Southeast Asia and its position in academia. Project Southeast Asia. http://projectsoutheastasia.com/wpcontent/uploads/2012/04/SEAS2012_OpeningPanel-Papers.pdf

Joaquin, E. (2014). The encounters of indifference of Filipino American faculty in higher education. [Doctoral dissertation, University of Georgia]. https://getd.libs.uga.edu/pdfs/joaquin_edward_201408_phd.pdf

Johnson-Thornton, R. (2014). Studying science: Students gaining access to the community of practice of environmental studies. [Doctoral dissertation, University of Rhode Island]. ProQuest Dissertations \& Theses.

Jones, S. R., Torres, V., \& Arminio, J. L. (2013). Meeting the obligations of high quality inquiry. In S. R. Jones, V. Torres, \& J. Arminio (Eds), Negotiating the complexities of qualitative research in higher education: Fundamental elements and issues (2nd ed., pp. 29-53). Routledge.

Kang, D. (2017). Eastern orientations: Thai middle-class gay desire for "white Asians." Culture, Theory and Critique, 58(2), 182-208. https://doi.org/10.1080/14735784.2017.1288580

Keo, P. T. (2020). An empirical exploration of Southeast Asian-Americans in education research: A qualitative meta-analysis. Journal of Southeast Asian American Education and Advancement, 15(2), 1-18. https://doi.org/10.7771/2153-8999.1210

Keo, P., \& Noguera, P. (2018). From the margins to the center: Debunking claims about Southeast Asian American masculinity. Equity \& Excellence in Education, 51(2), 199216. https://doi.org/10.1080/10665684.2018.1518172

Kiang, P. (1997). Pedagogies of life and death: Transforming immigrant/refugee students and Asian American studies. positions: East Asia cultures critique, 5(2), 551-577.

Kiang, P. N. C. (2008). [Special Issue on SEA Demographics] Response-Asian American studies. Journal of Southeast Asian American Education and Advancement, 3(1), 1-9. https://doi.org/10.7771/2153-8999.1105

Kwan, Y. (2020). "Navigating refugee subjecthood: Cambodian American education, identity, and resilience." Journal of Southeast Asian American Education and Advancement, 15(2), 1-12. https://doi.org/10.7771/2153-8999.1208

Kwan, Y. (2015). "Microaggressions and Hmong American Students." Bilingual Research Journal, 38(1), 23-44. https://doi.org/10.1080/15235882.2015.1017026

Lac, V. (2020a). From the flatlands of Oakland to the ivory towers of higher education: A counter-narrative of a Southeast Asian refugee. Journal of Southeast Asian American Education and Advancement, 15(2), 1-10. https://doi.org/10.7771/2153-8999.1206

Lac, V. (2020b). Fulfilling the intergenerational contract: A Southeast Asian American professor's journey (away from) home. In M. Barakat \& M. Rodriguez (Eds.), Immigrant 
faculty in the academy: Narratives of identity, resilience, and action (pp. 133-143). Routledge.

Le-Huynh, N.-T. (2008). Finding home: The journey of five first-generation Vietnamese Americans staging their home in Orange County. [Master's Dissertation, University of California, Los Angeles].

Lee, J., \& Zhou, M. (2015). The Asian American achievement paradox. Russell Sage Foundation.

Lee, S., Xiong, C., Pheng, L. M., \& Vang, M. N. (2017). The model minority maze: Hmong Americans working within and around racial discourses. Journal of Southeast Asian American Education and Advancement, 12(2), 1-20. https://doi.org/10.7771/2153$\underline{8999.1153}$

Lim, S. G. L. (1997). Among the white moon faces: An Asian-American memoir of homelands. The Feminist Press at CUNY.

Limki, R. (2015). Postcolonial excess(es): On the mattering of bodies and the preservation of value in India. [Doctoral dissertation, Queen Mary University of London]. https://qmro.qmul.ac.uk/xmlui/bitstream/handle/123456789/8978/Limki_Rashne_PhD_3 10315.pdf

Lo, B. (2018). Criminalization and second-generation Hmong American boys. Amerasia Journal, 44(2), 113-126. https://doi.org/10.17953/aj.44.2.113-126

Maramba, D. C., \& Nadal, K. (2013). Exploring the Filipino American faculty pipeline: Implications for higher education and Filipino American students. In D. C. Maramba \& R. Bonus (Eds.), The other students: Filipino Americans, education, and power (pp. 297-308). Information Age Publishing.

Milner, H. R. (2007). Race, culture, and researcher positionality: Working through dangers seen, unseen, and unforeseen. Educational Researcher, 36(7), 388-400. https://doi.org/10.3102/0013189x07309471

Mouavangsou, K. (2018). Because I am a daughter: A Hmong woman's educational journey. Journal of Southeast Asian American Education and Advancement, 13(1), 1-14. https://doi.org/10.7771/2153-8999.1166

Museus, S. D. (2013). Asian American students in higher education (1st ed.). Routledge. In S. D. Museus \& J. J. Park (2015). The continuing significance of racism in the lives of Asian American college students. Journal of College Student Development, 56(6), 551569. https://doi.org/10.1353/csd.2015.0059

Museus, S. D., \& Griffin, K. A. (2011). Mapping the margins in higher education: On the promise of intersectionality frameworks in research and discourse. New Directions for Institutional Research, 2011(151), 5-13. https://doi.org/10.1002/ir.395

Museus, S. D., Vue, R. Nguyen, T., \& Yeung, F. (2013). A Southeast Asian American identity model. In S. D. Museus, D. Maramba, \& R. Teranishi (Eds.), The misrepresented minority: New insights on Asian Americans and Pacific Islanders, and the implications for higher education. Stylus Publishing, LLC.

Nadal, K. (2016). Meet Anthony Ocampo, the professor who wrote a book on why Latinos and Filipinos are Primos. ReMezcla. https://remezcla.com/features/culture/filipino-latinos-ofasia-antony-ocampo-interview/

National Center for Educational Statistics. (2018). Annual report, digest of educational statistics. https://nces.ed.gov/programs/digest/2018menu_tables.asp 
National Science Foundation. (2018). Highest educational attainment of either parent of doctorate recipients: Selected years, 1993-2018. National Center for Science and Engineering Statistics. https://ncses.nsf.gov/pubs/nsf20301/data-tables/

Neighbors, T. (2016). The impact of cross-racial interactions on black male undergraduate perceptions of campus climate. [Doctoral dissertation, University of California, Los Angeles]. Escholarship. https://escholarship.org/uc/item/7x6969tv

Nguyen, M. (2020) Asian American and Native American Pacific Islander serving institutions (AANAPISIs): Serving and advocating for the educational needs of Southeast Asian American students. Journal of Southeast Asian American Education and Advancement, 15(2), 1-12. http://doi.org/10.7771/2153-8999.1205

Nguyen-Lam, K. (2002). Recruitment, preparation, and retention of teachers of color: The Southeast Asian American teachers' experience. [Unpublished dissertation]. California Institute of Integral Studies, California.

Noor, F. (2016). The discursive construction of Southeast Asia in 19th century colonial capitalist discourse. Amsterdam University Press.

Omi, M., \& Winant, H. (2014). Racial formation in the United States. Routledge.

Park, J. J., \& Teranishi, R. T. (2008). Asian American Pacific Islander serving institutions: Historical perspectives and future prospects. In M. Gasman, B. Baez, \& C. S. Turner (Eds.), Understanding minority-serving institutions (pp. 111-126). State University of New York Press.

Phetmixay, R. (Host). (2019). Healing out Lao'd [Audio podcast]. Buzzsprout. https://www.buzzsprout.com/234875/1166180-e6-latana-thaviseth-on-the-importance-ofhigher-education-continuing-family-legacy-of-building-community-across-lao-southeastasian-americans.

Phommasa, M. (2016). Bridging their own worlds: How Southeast Asian American students persist in the university. [Doctoral dissertation, University of California, Santa Barbara]. Escholarship. https://escholarship.org/uc/item/4fj263sp

Quinajon, R. (2019). Voices of Filipina academic success: Pinay educational experiences in doctoral programs. [Doctoral dissertation, University of Hawai'i at Manoa].

ScholarSpace. https://scholarspace.manoa.hawaii.edu/bitstream/10125/63176/Quinajon_hawii_0085A_1 0090.pdf

Ruiz, S. (2019). Another university is possible: Student activism against colonial education in the California State University system. About Campus, 24(2), 23-29. https://doi.org/10.1177\%2F1086482219869996

Sabharwal, M. (2011). High-skilled immigrants: How satisfied are foreign-born scientists and engineers employed at American universities?. Review of Public Personnel Administration, 31(2), 143-170. https://doi.org/10.1177\%2F0734371X11408572

See, S. (2017). The Filipino primitive: Accumulation and resistance in the American museum. New York University Press.

Sexton, J. (2008). Amalgamation schemes: Antiblackness and the critique of multiracialism. University of Minnesota Press.

Takei, I., Sakamoto, A., \& Kim, C. (2013). The socioeconomic attainments of non-immigrant Cambodian, Filipino, Hmong, Laotian, Thai, and Vietnamese Americans. Race and Social Problems, 5(3), 198-212. http://doi.org/10.1007\%2Fs12552-013-9089-7 
Tang, E. (2015). Unsettled: Cambodian refugees in the New York City hyperghetto. Temple University Press.

Tran, V. C., Lee, J., Khachikian, O., \& Lee, J. (2018). Hyper-selectivity, racial mobility, and the remaking of race. The Russell Sage Foundation Journal of the Social Sciences, 4(5), 188209. http://doi.org/10.7758/RSF.2018.4.5.09

Underhill, J. (2014). You didn't kill us all, you know—part two. Critical Refugee Studies Collective. https://criticalrefugeestudies.com/blog/you-didnt-kill-us-all-you-know-part$\underline{\text { two }}$

Uy, P. (2018). Unpacking racial identities: The salience of ethnicity in Southeast AsianAmerican youth's schooling experience. Race Ethnicity and Education, 21(3), 407-421. https://doi.org/10.1080/13613324.2016.1248820

Valverde, K., Pham, C., Yee, M., \& Mai, J. (2019). Killing machine: Exposing the health threats to Asian American women scholars in academia. In S. Hune, K. Valverde, \& W. Dariotis (Eds.), Fight the tower: Asian American women scholars' resistance and renewal in the academy (pp. 110-160). Rutgers University Press.

Valverde, K. (2013) Fight the tower: A call to action for women of color in academia. Seattle Journal for Social Justice, 12, 367-420.

Vang, C. Y. (2016). Southeast Asian Americans. In D. Yoo \& E. Azuma (Eds.), The Oxford handbook of Asian American history (pp. 88-103). Oxford University Press.

Vang, K. (2016). Educational experience of Southeast Asian students at three California State University of California campuses. [Doctoral dissertation, California State University, Fresno]. Dspace. https://scholarworks.calstate.edu/downloads/9s 1617152

Vang, M. (2018). Examining predictors of faculty-student engagement inside and outside the classroom for Southeast Asian American men in community college. Journal of Applied Research in the Community College, 25(1), 17-26.

Vo, L. (2012). Navigating the academic terrain: The racial and gender politics of elusive belonging. In G. Muhs, Y. Niemann, C. Gonzalez \& A. Harris (Eds.), Presumed incompetent: The intersections of race and class for women in academia (pp. 93-112). University Press of Colorado.

Whetsel-Ribeau, P. (2007). Retention of faculty of color as it relates to their perceptions of the academic climate at four-year predominantly white public universities in Ohio. [Doctoral dissertation, Bowling Green State University]. OhioLink. https://etd.ohiolink.edu/apexprod/rws_etd/send_file/send?accession=bgsu $1182282945 \& d$ isposition=inline

Williams Brown, K. N. (2017). The transnational narratives and struggles of Afro-Caribbean immigrant women teachers in New York City school districts. [Doctoral dissertation, Syracuse University.] Surface. https://surface.syr.edu/cgi/viewcontent.cgi?article=1785\&context=etd

Wisness, E. (2008). She's making history. Daily Planet. https://www.tcdailyplanet.net/shesmaking-history/

Wong, J. S., Lien, P. T., and Conway, M. M. (2005). Group-based resources and political participation among Asian Americans. American Politics Research, 33(4), 545-576. https://doi.org/10.1177\%2F1532673X04270521

Wright, W. E., \& Boun, S. (2011) Southeast Asian American education 35 years after initial resettlement: Research report and policy recommendations. Journal of Southeast Asian 
American Education and Advancement, 6(1), 1-91. https://doi.org/10.7771/2153$\underline{8999.1017}$

Xiong, S., Lor, D., \& Lorchueya, J. (2020). Understanding Southeast Asian American male student engagement experiences with community college faculty members. Community College Journal of Research and Practice, 45(10), 773-777. https://doi.org/10.1080/10668926.2020.1785354

Yamane, L. (2011) Asian Americans, glass ceilings, and PhDs. Asian American Policy Review, 22, 29-41.

Yang, C. (2017). In the shadows of overrepresentation: Hmong men and engineering education. [Master's thesis, California State University, Sacramento].

Yi, V., Mac, J., Na, V. S., Venturanza, R. J., Museus, S. D., Buenavista, T. L., \& Pendakur, S. L. (2020). Toward an anti-imperialistic critical race analysis of the model minority myth. Review of Educational Research, 90(4), 542-579. https://doi.org/10.3102/0034654320933532 


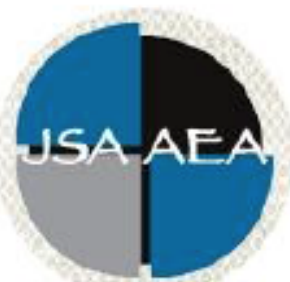

Vol.16 Iss.1 (2021)

\section{Journal of Southeast Asian American \\ Education and Advancement}

\author{
Editor \\ Dr. Wayne E. Wright \\ Purdue University \\ Associate Editors \\ Dr. Chhany Sak-Humphry \\ University of Hawaii at Manoa \\ Dr. Phitsamay Sychitkokhong Uy \\ University of Massachusetts, Lowell \\ Book Review Editor \\ Dr. Vichet Chhuon \\ University of Minnesota \\ Creative Works Editor \\ Bryan Thao Worra \\ Lao Assistance Center \\ Journal Manager \\ Vikrant Chap \\ Purdue University
}

Editorial Review Board

Dr. Steve Arounsack

California State University, Stanislaus

Dr. Sovicheth Boun

Salem State University

Dr. Virak Chan

Purdue University

Dr. Loan Dao

University of Massachusetts Boston
Dr. Carl L. Bankston III

Tulane University

Dr. Phala Chea

Lowell Public Schools

Dr. George Chigas

University of Massachusetts, Lowell

Dr. Hien Duc Do

San Jose State University 


\author{
Dr. Linh Dang \\ KIPP DC Headquarters \\ Dr. Sophal Ear \\ Occidental College \\ Dr. Vincent K. Her \\ University of Wisconsin, Eau Claire \\ Dr. Nancy H. Hornberger \\ University of Pennsylvania \\ Dr. Peter Tan Keo \\ New York University \\ Dr. Yvonne Kwan \\ San Jose State University \\ Dr. Ravy Lao \\ California State University, Los Angeles \\ Dr. Stacey Lee \\ University of Wisconsin, Madison \\ Dr. Jacqueline Mac \\ Northern Illinois University \\ Dr. Bic Ngo \\ University of Minnesota \\ Dr. Leakhena Nou \\ California State University, Long Beach \\ Dr. Mark Pfeifer \\ SUNY Institute of Technology \\ Dr. Loan T. Phan \\ University of New Hampshire \\ Dr. Karen Quintiliani \\ California State University, Long Beach \\ Dr. Angela Reyes \\ Hunter College \\ The City University of New York \\ Dr. Fay Shin \\ California State University, Long Beach \\ Dr. Christine Su \\ College of San Mateo \\ Dr. Alisia Tran \\ Arizona State University \\ Dr. Khatharya Um \\ University of California, Berkeley \\ Dr. Kim Tran \\ University of California, Los Angeles, \\ Glendale Community College \\ Dr. Molly Wiebe \\ The University of Texas at Austin
}

Dr. Changming Duan

University of Missouri-Kansas City

Dr. Sothy Eng

Lehigh University

Dr. Jeremy Hein

University of Wisconsin, Eau Claire

Dr. Peter Nien-Chu Kiang

University of Massachusetts, Boston

Dr. Kevin K. Kumashiro

University of Illinois, Chicago

Dr. Ha Lam

Independent Scholar

Dr. Jonathan H. X. Lee

San Francisco State University

Dr. Monirith Ly

Royal University of Phnom Penh

Dr. Sue Needham

California State University, Dominguez Hills

Dr. Max Niedzwiecki

Daylight Consulting Group

Dr. Clara Park

California State University, Northridge

Dr. Giang Pham

University of Massachusetts Amherst

Dr. Malaphone Phommasa

University of California Santa Barbara

Dr. Kalyani Rai

University of Wisconsin-Milwaukee

Dr. Cathy J. Schlund-Vials

University of Connecticut, Storrs

Dr. Nancy J. Smith-Hefner

Boston University

Dr. Yer J. Thao

Portland State University

Dr. Monica M. Trieu

Purdue University

Dr. Silvy Un

Saint Paul Public Schools

Dr. Linda Trinh Vo

University of California, Irvine

Dr. Varaxy Yi Borromeo

California State University, Fresno

Dr. Yang Sao Xiong

The University of Wisconsin-Madison 


\section{Dr. Zha Blong Xiong}

University of Minnesota

\section{Doctoral Student Editorial Review Board}

Diana Chandara
University of Minnesota-Twin Cities
Bao Diep
University of Minnesota-Twin Cities
Vanessa Sovanika Na
University of California San Diego
Khoi Nguyen
George Mason University
Hoa Nha Nguyen
Boston College
Linda Marie Pheng
University of Wisconsin-Madison
Latana Thaviseth
University of California Los Angeles
Melissa Vang
San Diego State University

Diana Chandara

Bao Diep

Kassandra Chhay

University of Minnesota-Twin Cities

Annie BichLoan Duong

San Joaquin County Office of Education

Nielson Hul

Cornell University

Dung Minh Mao

University of Minnesota-Twin Cities

Thien-Huong Ninh

University of Southern California

Krissyvan Truong

Claremont Graduate University

Mai Vang

University of Massachusetts Boston

Thong Vang

University of Minnesota-Twin Cities

San Diego State University

Claremont Graduate University 